\title{
Comparative study between two techniques of incisional hernia repair with polypropylene mesh in rabbits ${ }^{1}$
}

\author{
Estudo comparativo entre duas técnicas de tratamento da hérnia incisional em coelhos \\ utilizando a tela de polipropileno
}

\author{
José Guilherme Minossi', Carlos Antonio Caramori" ${ }^{I I}$, Celso Vieira de Souza Leite ${ }^{\mathrm{III}}$, Luiz Eduardo Naresse ${ }^{\mathrm{III}}$

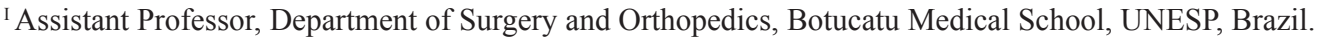

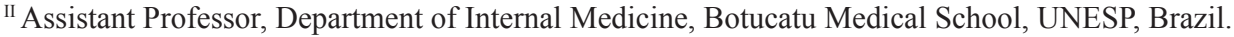



\begin{abstract}
Purpose: To compare two different incisional hernia repair techniques (repair with a polypropylene mesh reinforcement on the peritonium-aponeurosis versus polypropylene mesh sutured to the borders of the hernial ring as a bridge) in rabbits. Methods: Incisional hernia was experimentally developed through a 4-cm median incision in 60 rabbits. After 30 days, half of the animals were operated for primary wall closure and placement of a polypropylene mesh reinforcement, while the other half had a polypropylene mesh sutured to the borders of the hernial ring as a bridge. Clinical development, scar breaking strength, as well as gross, microscopic and morphometric parameters were evaluated in all animals 30, 60, and 90 days after repair. Results: No significant differences in breaking strength or histological parameters were observed between groups at any time point studied. No statistical difference regarding complications was detected, although denser and firmer adhesions to the abdominal wall were seen after the mesh was placed as a "bridge". Conclusions: No significant differences between the incisional hernia repair techniques assessed were observed regarding breaking strength, and histological and morphometric parameters. The number of complications was similar in both study groups. However, adhesion of abdominal cavity organs to the scar area was much denser after the placement of a mesh to bridge the defect.
\end{abstract}

Key words: Hernia, Ventral. Polypropylenes. Surgical Mesh. Rabbits.

\section{RESUMO}

Objetivo: Comparar duas técnicas de tratamento da hérnia incisional em coelhos utilizando a tela de polipropileno apoiando um reforço peritônio - aponeurótico ou suturada nas bordas do anel herniário 'em ponte". Métodos: Foram operados 60 coelhos para a produção de hérnia incisional, em uma incisão mediana de 4 centímetros. Após 30 dias, metade dos animais foram operados com o fechamento primário da parede, com colocação de uma tela de polipropileno apoiando o reforço e a outra metade dos animais com a colocação da tela suturada nas bordas do anel herniário "em ponte”. Os animais foram avaliados com 30 (M1), 60 (M2)e 90 (M3) dias de pós-operatório. Os parâmetros analisados foram a evolução clínica, análise da força de ruptura da cicatriz, estudo macroscópico, análise microscópica e morfométrica. Resultados: Não foram observadas diferenças significantes com relação a força de ruptura e estudos histológicos nos dois grupos e vários momentos estudados. Não houve diferença estatística com relação às complicações, embora os animais que receberam a tela "em ponte" tiveram aderências mais firmes e intensas à parede abdominal. Conclusões: As duas técnicas utilizadas para correção da hérnia incisional em coelhos não mostraram diferenças significantes quanto a força de ruptura, análise histológica e morfométrica. O número de complicações foi semelhante, porém a aderência de órgãos da cavidade abdominal à área de cicatriz foi muito mais intensa no grupo em que a tela foi colocada "em ponte".

Descritores: Hérnia Ventral. Polipropilenos.Telas Cirúrgicas. Coelhos.

${ }^{1}$ Research performed at Botucatu Medical School. São Paulo State University (UNESP), Brazil.

\section{Introduction}

Incisional hernia, also termed eventration, laparocele, or postoperative hernia is the protrusion of viscera through orifices or areas of the abdominal wall weakened by traumas or surgical incisions.
In a large number of cases, incisional hernia is an iatrogenic condition. In contrast to other parietal hernias, which occur through naturally weak anatomic spots of the abdominal wall ${ }^{1}$. 
No precise information on the actual local incidence of incisional hernia in the general population is available because bad outcomes are either underreported or neglected. Reported rates range from 1.3 to $11.5 \%$.

The incidence of incisional hernia is age-related. Indeed, $92 \%$ of the patients with this condition are older than 40 years, with peak age range of 40-70 years. In the elderly, the higher incidence of incisional hernias is associated with concurrent metabolic, degenerative and inflammatory diseases of the bile ducts and colon in addition to cardiac and pulmonary disorders, especially those of a chronic pulmonary obstructive nature, and arteriosclerosis.

Incisional hernias are most frequently caused by median longitudinal and external pararectal incisions whose courses do not respect some anatomophysiological principles of the abdominal wall. Transverse and internal pararectal incisions should be preferred as they section fewer nerves and muscle fibers other than those of the abdominal smooth muscle. Moreover, proper dieresis and synthesis of the wall anatomic planes, adequate use of threads and drains, as well as a set of pre- and postoperative care measures are critical to incisional hernia prevention ${ }^{2}$.

The treatment of incisional hernia is usually surgical. A great number of surgical procedures are available for the correction of this condition. Repair can be performed with or without using a synthetic prosthesis.

Non-prosthetic repair may be simply done through the synthesis of the abdominal wall by planes, and is indicated for small hernias, which normally have a hernial ring of less than ten centimeters. Another option is the technique proposed by Lazaro da Silva ${ }^{3}$, in which the anatomy of the abdominal wall is reconstructed by peritoneal-aponeurotic transposition in three planes. Besides not requiring the use of a prosthesis, this technique allows the repair of hernias with larger rings.

Synthetic prostheses have been used since 1948. Since then, many biomaterials have been tested. Today, polypropylene is the most commonly used for its lower cost and acceptable adverse events. Among prosthetic methods, the technique of Rives offers the best results with a low rate of recurrence 4 . In some cases, repair may be done by suture approximation with prosthesis reinforcement. However, the hernial ring is often too wide and the hernial sac is inconsistent not allowing the performance of this technique or even peritoneal-aponeurotic transposition. In these circumstances, the use of a prosthesis bridge is necessary.

The purpose of this study was to compare two treatments for incisional hernia experimentally developed in rabbits divided into two groups (G1- repair with a polypropylene mesh reinforcement, and G2 - repair with a polypropylene mesh sutured as a bridge). Comparison was based on clinical examination of the animals, breaking strength assessment, microscopy and morphometry.

\section{Methods}

The research was approved by the Ethics Committee in Research of the Botucatu Medical School, Sao Paulo State University.

Incisional hernias were produced in 60 adult male rabbits weighing 2.500-3.000 grams. The animals were anesthetized with endovenous sodium pentobarbital $(30 \mathrm{mg} / \mathrm{kg})$, and a median laparotomy with an incision length of approximately four centimeters was performed $10-12 \mathrm{~cm}$ from the xyphoid process.

Incision closure was restricted to skin suture with separate stitches using 4-0 monofilament thread.

The animals with surgical wound infection were excluded. Those with an infection-free incisional hernia were divided into two groups and reoperated after 30 days for repair. In Group 1 (G1), the hernial sac was isolated and resected, and incisional hernias were repaired through the approximation and suture of the muscle-aponeurotic plane with 4-0 monofilament nylon thread with separate stitches, and the placement of a $6 \mathrm{~cm} \times 2 \mathrm{~cm}$ polypropylene mesh patch as a reinforcement, which was fixed with the same suture thread. In Group 2 (G2), isolation and resection of the hernial sac was followed by the placement of a polypropylene mesh patch, of the same size as the one used in G1, which was sutured to the borders of the hernial ring with 4-0 monofilament nylon thread without approximation of the muscle aponeurotic plane (as a bridge). In both groups, the skin was sutured with separate stitches using 4-0 monofilament thread.

Study parameters were assessed 30,60, and 90 days after repair. Clinical examination included weekly weight measurement and observation of the physical status and surgical incision. The animals showing infection or mesh extrusion were excluded.

At 30,60, and 90 days after operation, the animals were anesthetized and reoperated. A rectangular fragment of the abdominal wall comprising the entire scar was removed. The skin was carefully dissected from the deeper planes and discarded. From the fragment removed, three $1-\mathrm{cm}$ segments were cut perpendicular to the suture line. The upper segment was used for histopathological analysis, the middle segment for breaking strength measuring, and the lower segment was frozen at $-20^{\circ} \mathrm{C}$ for biochemical testing.

Breaking strength was determined through the use of a Universal Assay Machine (EMIC, modelo DC10000) immediately after the tissue segment was placed in saline at $37^{\circ} \mathrm{C}$.

For morphological analysis, the abdominal wall segment was fixed in 10\% formaldehyde for 48 hours, immersed in $70 \%$ alcohol for 24 hours, embedded in paraffin, cut into $0.5 \mu \mathrm{m}$-thick sections and stained with Hematoxylin-Eosin and Masson's trichrome. Slides were objectively analyzed by the same examiner.

The slides stained with Masson's trichrome were used to quantify collagen volume fraction in the scar area by videodensitometry. Areas of interest (AOI) measuring $2 \mathrm{~cm} \mathrm{x} 0.5 \mathrm{~cm}$ in the scar region defined by the margins of the muscles on both sides of the scar were examined under an optical microscope (Leica DMLB, ocular Lplan 10x/25, objective PL Fluotar 5x). Images were captured by a camera (Köhler CTV 500, NTSC system, 0.63x coupler lens) and digitalized through a computer (AST Bravo MS-T PRO 6200, Pentium Pro, Windows NT) with Software Image Pro-Plus ${ }^{\mathrm{TM}}$, Version 3.0 (Media Cybernetics, Silver Spring, Maryland, USA, 1997), in the Experimental Laboratory of the Department of Internal Medicine, Botucatu Medical School, Sao Paulo State University/UNESP.

Tissue elements were identified according to color levels in the area of interest (AOI). Fibrosis volume fraction was calculated. The digitized profile was analyzed by a computer that calculated the volume fraction of fibrosis as the sum of all areas 
containing fibrosis divided by the total segment area. Fibrosis fraction corresponded to the percentage (\%) of fibrosis on the total cross-sectional extrusion area.

Statistical analysis was performed using the test of Mann-Whitney for independent samples. All statistical discussions were based on a significance level of $5 \%(p \leq 0.05)$.

\section{Results}

\section{Clinical evaluation}

Weight gain was observed in all animals. The only significant difference was seen at 60 days in G1 (Table 1).

TABLE 1 - Comparison between techniques-weight gain

\begin{tabular}{cccccc}
\hline Weight gain & $\boldsymbol{n}$ & Mesh reinforcement & $\boldsymbol{n}$ & Mesh bridge & $\boldsymbol{p}^{(I)}$ \\
\hline Variation $^{(2)}(\%)(30$ days after surgery) & 10 & $13.7(9.3 ; 19.6)$ & 10 & $14.2(12.6 ; 21.9)$ & 0.496 \\
Variation $^{(2)}(\%)(60$ days after surgery) & 10 & $21.2(16.9 ; 28.2)$ & 10 & $14.8(5.2 ; 18.2)$ & 0.028 \\
Variation $^{(2)}(\%)(90$ days after surgery) & 10 & $38.6(31.4 ; 42.0)$ & 9 & $21.1(13.6 ; 39.7)$ & 0.072
\end{tabular}

(1) Test of Mann-Whitney for independent samples. Descriptive summary (median, quartile).

(2) Weight at sacrifice in relation to initial weight.

After thirty days of surgery, $50 \%$ of the rabbits submitted to the mesh support technique weighed, at most, $13.7 \%$ above their initial weight, while $50 \%$ of the 10 animals submitted to the mesh bridge technique weighed at most $14.2 \%$ above their initial weight. No evidence of difference in weight gain was observed 30 $(\mathrm{p}=0.496)$, and 60 days after operation $(\mathrm{p}=0.072)$. However, at day 60 , there was evidence enough to conclude that weight gain was higher in the animals submitted to the mesh support technique than in those submitted to the mesh bridge technique.
In each group there was one case of death due to wall infection. The first death occurred on day 7 , and the other on day 10 after operation.

\section{Breaking strength assessment}

Table 2 shows that no significant difference in breaking strength was observed between techniques at 30,60, and 90 days postoperation.

TABLE 2 - Comparison between techniques-breaking strength

\begin{tabular}{lccccc}
\hline Breaking strength $(\boldsymbol{N})$ & $\boldsymbol{n}$ & Mesh reinforcement & $\boldsymbol{n}$ & Mesh bridge & $\boldsymbol{p}^{(*)}$ \\
\hline 30 days after surgery & 10 & $3154.5(2358.2 ; 3737.0)$ & 10 & $2534.5(1637.5 ; 3344.5)$ & 0.131 \\
& 10 & $2460.5(1695.7 ; 3004.7)$ & 10 & $1726.0(1250.5 ; 2644.0)$ & 0.174 \\
60 days after surgery & 10 & $1922.5(1288.0 ; 2066.7)$ & 10 & $1849.0(1677.2 ; 3257.5)$ & 0.450 \\
90 days after surgery & 10
\end{tabular}

(*)Test of Mann-Whitney for independent samples. Descriptive summary (median, quartile).

No evidence of significant difference in breaking strength was observed between techniques at any of the postoperative times assessed.

\section{Gross examination}

Gross examination revealed wall infection in three animals of group 1 and four animals of group 2. All infection cases were detected before 10 postoperative days. Two animals from each group showed mesh extrusion 60 days after operation, and were excluded.

At sacrifice, all animals showed bowel loops adherent to the operated abdominal wall. Such adhesions were denser and firmer in $\mathrm{G} 2$ animals. 


\section{Microscopic examination}

Common optical microscopy showed no significant differences between groups.

At day 30, collagen fibers densely lay parallel to the mesh occupying its entire exposed area. In most animals, discrete foreign body reaction was observed with no difference between groups.
At 60 , and 90 days after operation, no inflammatory process was observed. There was greater collagen remodeling, with finer parallel fibers lying on the synthetic material, with no difference between groups.

Morphometric analysis revealed no significant difference between groups at any of the time points assessed (Table 3).

TABLE 3 - Comparison between techniques-morphometry

\begin{tabular}{cccccc}
\hline \multicolumn{1}{c}{ Morphometry } & $\boldsymbol{n}$ & Mesh reinforcement & $\boldsymbol{n}$ & Mesh bridge & $\boldsymbol{p}^{(*)}$ \\
\hline 30 days after surgery & 9 & $0.0167(0.0054 ; 0.0276)$ & 9 & $0.0312(0.0113 ; 0.2835)$ & 0.251 \\
& 9 & $0.0273(0.0009 ; 0.2576)$ & 9 & $0.1260(0.0118 ; 0.2039)$ & 0.508 \\
60 days after surgery & 9 & $0.0069(0.0000 ; 0.1043)$ & 9 & $0.0950(0.0006 ; 0.1339)$ & 0.301 \\
90 days after surgery & 9 & 0.01 & \\
\hline
\end{tabular}

(*) Test of Mann-Whitney for independent samples. Descriptive summary (median, quartile).

No evidence of significant differences in morphometry was observed between techniques at any of the postoperative times assessed.

\section{Discussion}

The treatment of large or medium-sized incisional hernias can be based on a considerable number of techniques using protheses that may be placed as reinforcements following tissue reapproximation or as bridges ${ }^{5}$. This latter method is not employed unless there is a large gap between the borders to be sutured or when the hernial sac cannot be used. Eventually, the mesh may be placed as a bridge over a non-manipulated hernial sac.

Polypropylene prostheses were introduced in Brazil by Falci $^{6}$, and have been the most used synthetic material used in the country, especially when avoiding extensive tension on the suture line joining the aponeurotic borders is desired ${ }^{7,8}$.

Even though numerous studies on incisional hernia repair in experimental animals ${ }^{9}$ are available, there few no reports on scar healing when a mesh is placed as a bridge over the hernial ring.

The experimental model used here was effective in reproducing incisional hernia in all cases and was able to simulate the conditions encountered after median laparotomy, in contrast with the model produced by the removal of a muscle-aponeurotic fragment from the abdominal wall ${ }^{10}$, which is frequently reported in the literature ${ }^{11,12}$.

Clinical evaluation revealed no differences in animal activity and food consumption, although weight gain was statistically higher in group 1 at 60 days postoperation.

Breaking strength assessment, despite exposing the scar to extremely adverse situations that are hardly encountered after operation, has been frequently used to determine surgical wound tissue cohesion at different healing stages ${ }^{13,14}$. In this study, no significant statistical difference in this variable was observed between groups at all time points. It may thus be inferred that both types of procedure were followed by a similar healing process in the experimental model used.

From the histological standpoint, the regenerative phenomena observed in G1 were similar to those seen in G2, in which the mesh was placed as a bridge on the hernial ring, at all time points investigated. This fact suggests that fibroblast migration, with consequent collagenogenesis, occurs through the pores of the mesh, giving rise to intense fibrogenesis and filling the mesh empty spaces with collagen.

The inflammatory process, as well as the peritoneal adhesions observed here resembled those reported by Quitzan et al. ${ }^{15}$ comparing bovine pericardium with polyester mesh, which is more frequently used in Europe than in our country. Although the adhesions observed in this study did not lead to subocclusion or fistula, such complications may eventually occur at times later than those assessed in this experiment, and may be the subject of further studies.

Morphometry is another method that has been used to study the healing of bone ${ }^{16}$, $\operatorname{skin}^{17}$, mesenterium ${ }^{18}$, intestinal anastomosis ${ }^{19}$ and abdominal wall ${ }^{10,20}$.

In this experiment, Masson's trichrome was used in the assessment of collagen. This technique provided good collagen fiber selectivity, although pricrosirius is known to be more specific. However, none of these methods allows differentiating collagen types.

Despite the difficulty in obtaining material for microscopy, caused by the fact that meshes make it difficult to cut thin sections, it was possible to observe parallel-arranged collagen fibers on the entire scar area in both study groups. This observation led us to once more infer that fibroblast migration occurred through the pores of the inorganic mesh, resulting in similar collagen amounts in both groups. 


\section{Conclusions}

Both techniques used for incisional hernia repair in rabbits yielded no differences in breaking strength, as well as in histological and morphometric parameters. The number of complications was similar in both experimental groups. However, adhesion of abdominal cavity organs to the scar area was greater when the mesh was placed as a bridge.

\section{References}

1. Abdala P. Hérnias abdominais: análise da incidência de 2000 casos. Rev Col Bras Cir. 1981;8:67-9.

2. Akman PC. A study of five hundred incisional hernias. J Int Col Surg. 1962;37:125-42.

3. Lázaro da Silva A. Surgical correction of longitudinal median of paramedian incional hérnia Surg Gynecol Obstet. 1979;148:579-83.

4. Gonzáles JCM. Reparo incisional com prótese - técnica de Rives. In: Melo RM, Abdalla RZ. Hérnias da parede abdominal. 1ed. São Paulo: Iátria; 2007. p.344-64.

5. Wantz GE. Incisional hernioplasty with mensilene. Surg Gynecol Obstet. 1991;172:129-37.

6. Falci F. Reparação de hérnia incisional com prótese de Marlex. J Bras Med. 1969;17:15-20.

7. Lichtenstein IL, Shulman AG, Amid PK, Montllor MM. The tension-free hernioplasty. Am J Surg. 1989;157:188-93.

8. Stoppa RE. The treatment of complicated groin and incisional hernias. World J Surg. 1989;13:545-54.

9. Vaz M, Krebs RK, Trindade EM, Trindade MR. Fibroplasia after polypropylene mesh implantation for abdominal wall hérnia repair in rats. Acta Cir Bras 2009;24(1):19-25.

10. Melo RM, Gouvêa CMCP, Silva AL. Efeito do ultra-som na prevenção da hérnia incisional mediana no rato. Acta Cir Bras. 2005;20:100-8.
11. Gianlupi A, Trindade MRM. Comparação entre o uso de fio inabsorvível (polipropileno) e fio absorvível (poliglactina 910) na fixação de prótese de polipropileno em correção de defeitos músculo-aponeuróticos da parede abdominal. Estudo experimental em ratos. Acta Cir Bras. 2004;19:94-102. 12. d'Acampora AJ, Kestering DM, Soldi MS, Rossi LF. Experimental study comparing the tensile strenght of different surgical meshes following aponeurotic-muscle deformity synthesis on Wistar rats. Acta Cir Bras. 2007;22:47-52.

13. Minossi JG, Leite CVS, Naresse LE, Rodrigues MAM, Argelelli AYO, Kobayasi S. Efeito do diclofenaco de sódio na cicatrização da parede abdominal de ratos. Estudo histopatológico, da força de ruptura e do colágeno tecidual. Acta Cir Bras. 2001;16:146-54.

14. Watanabe ALC, Watanabe LM. Efeito do tenoxicam sobre a cicatrização da parede abdominal: estudo experimental em ratos. Acta Cir Bras. 2005;20:140-3.

15. Quitzan JG, Rahal SC, Rocha NS, Crocci AJ. Comparação entre pericárdio bovino preservado em glicerina e malha de poliéster no preparo de falhas da parede abdominal de ratos. Acta Cir Bras. 2003;18:297-301. 16. Alkan A, Erdem E, Gunhan O, Karasu C. Histomorphometric evaluation of the effect of doxycyline on the healing of bone' defects in experimental diabetes mellitus: a pilot study. J Oral Maxillofac Surg. 2002;60:898-904.

17. Mellin TN, Cashen DE, Ronan JJ, Murphy BS, di Salvo J, Thomas K. Acidic fibroblast growth factor accelerates dermal wound healing in diabetic mice. J Invest Dermatol. 1995;104:850-5.

18. Franzén LE, Roberg K. Impaired connective tissue repair in Streptozotocin-Induced Diabetes shows ultrastructural signs of impaired contraction. J Surg Res. 1995;58:407-14.

19. Verhofstad MHJ, Lange WP, van Der Laak Jalum, Verhofstad AAJ, Hendriks T. Microscopic analysis of anastomotic healing in the intestine of normal and diabetic rats. Dis Colon Rectum. 2001;44:423-31.

20. Biondo-Simões MLP, Westphal VL, Paula JB, Borsato KS, Noronha L. Síntese de colágeno após a implantação de telas de polipropileno em parede abdominal de ratos jovens e velhos. Acta Cir Bras. 2005;20:300-4.

Conflict of interest: none Financial source: none

\section{Correspondence:}

José Guilherme Minossi

Faculdade de Medicina de Botucatú

Departamento de Cirurgia e Ortopedia

Distrito de Rubião Junior, s/n

18618-970 Botucatú - SP Brasil

Phone: (55 14)3811-6269

jminossi@uol.com.br

Received: February 18, 2010

Review: April 19, 2010

Accepted: May 20, 2010

\section{How to cite this article}

Minossi JG, Caramori CA, Leite CVS, Naresse LE. Comparative study between two techniques of incisional hernia polypropylene mesh repair in rabbits. Acta Cir Bras. [serial on the Internet] 2010 Sept-Oct;25(5). Available from URL: http://www.scielo.br/acb 